\title{
Effect of Momordica charantia on the removal of arsenic from different organs of arsenic-treated rat
}

\author{
Shakila Akhter and Mir Misbahuddin
}

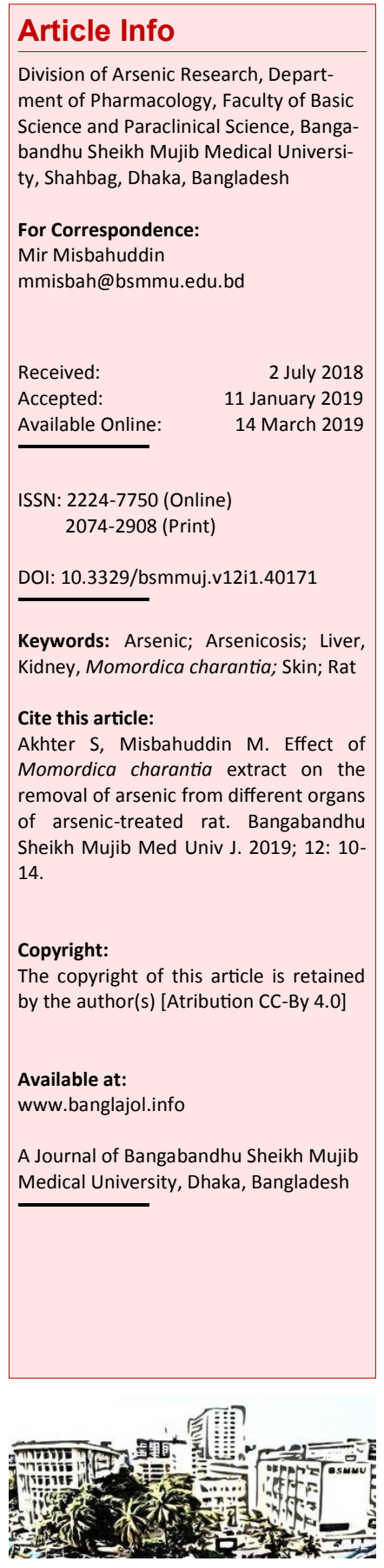

\section{Abstract}

The present study was designed to examine the effect of Momordica charantia ethanol extract on the removal of arsenic from different organs of the arsenic-loaded rat. The rats $(n=30)$ were divided into 5 groups: a) control, b) arsenic-treated $(200 \mu \mathrm{g} / \mathrm{L}), \mathrm{c})$ extract-treated ( $50 \mathrm{mg} /$ day), and d) arsenic plus extract-treated (50 or $200 \mathrm{mg} / \mathrm{kg}$ ). The rats were sacrificed on day 61 . The study revealed that there were significant accumulation of arsenic in the liver, kidneys, intestine and skin. On the other hand, there was significant decrease in glutathione level in the liver. The administration of extract significantly decreased the amount of arsenic in all the organs tested and increased the glutathione level significantly in the liver. The maximum reduction of arsenic was found in skin $(100 \%)$, liver $(91.2 \%)$, intestine $(89.2 \%)$ and kidney $(83.1 \%)$. The maximum elevation of glutathione in liver was $48.3 \%$. In conclusion, $M$. charantia reduces the arsenic level from different organs of the arsenic-loaded rat.

\section{Introduction}

Arsenicosis is usually due to chronic ingestion of high concentration of arsenic through drinking water. However, it has no specific treatment. Some investigators suggest the effectiveness of retinal, beta-carotene, 1 zinc, $\underline{2}$ ascorbic acid, $\underline{3}$ selenium, $\underline{4}$ tocopherol $\underline{5}$ and spirulina. $\underline{6}$ These treatments require several months to get some improvement. However, long duration of treatment may affect the patient compliance. In addition, recurrence occurs after the stoppage of treatment. For this reason, new treatment option is required.

Momordica charantia is used as a vegetable. It has the medicinal properties such as antidiabetic, antitumour, antibacterial, antiviral, antihelmintic and abortifacient.

Chronic arsenic toxicity decreases the intracellular glutathione level. M. charantia is a rich source of flavonoids. Flavonoids increase the intracellular glutathione level by transactivation of the $\gamma$-glutamylcysteine.7 Glutathione promotes the methylation capacity in liver which is the main metabolic pathway of arsenic and facilitates the excretion of arsenic that consequently reduces the arsenic burden. 8

In this study, it was examined whether the extract of $M$. charantia could remove the arsenic from different organs of arsenic-treated rat.

\section{Materials and Methods}

The study was carried out from September 2016 to January 2018. The M. charantia (30 kg) was purchased from the local market. They were washed and chopped without seeds. They were, then, dried in open air at room temperature for 3 days.

\section{Extraction procedure}

$M$. charantia was taken in an amber colored container. They were soaked in $80 \%$ ethanol at room temperature. After 24 hours, this was filtered by Whatman filter paper. The filtrate was condensed in a rotatory vacuum evaporator at $60^{\circ} \mathrm{C}$ and at rotations of $100 \mathrm{rpm}$. Then, the condensed thick extract was obtained (130 g).

\section{Brine shrimp lethality assay}

Serial dilution of the $M$. charantia extract: Two milligram of $M$. charantia extract was measured using an analytical balance. The test tubes were taken and labeled. The extract dissolved in 2 $\mathrm{mL}$ solution to prepare the stock solution. Serial dilution of the stock solution was done to prepare the concentration of 1000, 200, 50 and 1 $\mu \mathrm{g} / \mathrm{mL}$. These prepared solutions were taken into the four test tubes labeled as 1-4 that contained 10 nauplii and $1 \mathrm{~mL}$ of seawater.

Hatching of brine shrimp: Artemia salina (brine shrimp) eggs were collected from the local 
market. A rectangular jar was filled with $3 \mathrm{~L}$ of water. 9 Twenty-seven gram of table salt was to it and mixed with the jar water using a spatula. Proper aeration maintained by putting the tip of an airline from an air pump into the bottom of the jar. Brine shrimp eggs (15 g) were mixed into the jar water. A light (60 watt bulb) was switched on and placed a few inches away from the jar.

After 72 hours, the nauplii were hatched. Ten actively moving nauplii were transferred to each test tube containing different concentration of $M$. charantia extract by using Pasteur pipette and motility was observed after 0,2 and 24 hours.

\section{Experimental procedure}

Maintenance of the rat house: The environment of the rat house was properly maintained where the dark/ light cycle $12 / 12$ hours, temperature $25-30^{\circ} \mathrm{C}$. Wasted products were removed regularly. It was essential for animal well-being, the quality of animal research and also the health and safety of the investigator.

Prepare the rat cases: The polypropylene plastic cages were needed for keeping the rats. A layer of wood shavings was placed on the floor of the cages. Each cage was properly labeled for identification of different groups. The cage was cleaned regularly during the experimental period.

Isolation of the experimental rats: Thirty rats (LongEvans Norwegian strains, adult healthy male) were isolated for this study. The weight of the rats was 200-250 g. The rats were divided into five groups: a) control, b) arsenic-treated (200 $\mu \mathrm{g} / \mathrm{L}), \mathrm{c})$ extracttreated $(50 \mathrm{mg} /$ day), and d) arsenic plus extracttreated (50 or $200 \mathrm{mg} / \mathrm{kg}$ ) (Table I). The control group received only food and water ad libitum every day for 60 days. The arsenic group received arsenic contaminated water $200 \mu \mathrm{g} / \mathrm{L}$ ad libitum for the first 30 days followed by normal diet and water ad libitum for another 30 days. The extract group received normal diet and water ad libitum for the first 30days followed by M. charantia extract 200 $\mathrm{mg} /$ day for another 30 days. The arsenic plus extract (50 or $100 \mathrm{mg}$ ) exposed group received arsenic contaminated water for the first 30 days followed by $M$. charantia extract 50 or $100 \mathrm{mg} /$ day for another 30 days. Rats were sacrificed on day 61 .

Preparation of arsenic solution $(1 \mathrm{mg} / \mathrm{mL})$ : One hundred and thirty-two milligram of arsenic trioxide (E. Merck, Germany) was required to prepare arsenic trioxide stock solution $(1 \mathrm{mg} / \mathrm{mL})$. It was taken in a measuring cylinder $(100 \mathrm{~mL})$ and $100 \mathrm{~mL}$ of distilled water was added to it. The arsenic was not completely dissolved in water. So, $5 \%$ sodium hydroxide was added drop by drop until the arsenic trioxide dissolves completely. Then, it was kept in the refrigerator at $0-4^{\circ} \mathrm{C}$ before use.

Administration of arsenic contaminated water: Arsenic contaminated drinking water $(200 \mu \mathrm{g} / \mathrm{L})$ was prepared from the stock solution. Then, about $200 \mathrm{~mL}$ of arsenic water was given every day in the concerned groups of rats by water feeding bottle. Each rat took water ad libitum. In an average each rat took $30 \mathrm{~mL}$ of arsenic contaminated water per day.

Dilution of $M$. charantia extract in the solvent: $M$. charantia extract (3 g) was dissolved in $15 \mathrm{~mL}$ solvent $(1.5 \mathrm{~mL}$ ethanol $+13.5 \mathrm{~mL}$ distilled water) to obtain the concentration of extract $200 \mathrm{mg} / \mathrm{mL}$. M. charantia extract $(400 \mathrm{mg})$ was dissolved in $8 \mathrm{~mL}$ solvent $(0.8 \mathrm{~mL}$ ethanol $+7.2 \mathrm{~mL}$ distilled water) to obtain the concentration of $50 \mathrm{mg}$ for each rat.

Administration of $M$. charantia extract: Each rat of two groups (arsenic plus extract $200 \mathrm{mg}$ group and extract group) was fed $200 \mathrm{mg} / \mathrm{mL}$ extract orally everyday for one month at 9.00-10.00 am. Another group of arsenic plus extract $(50 \mathrm{mg}$ ) was given 50 $\mathrm{mg} / \mathrm{mL}$ extract orally everyday for one month at the same time.

\section{Sacrifice of animals}

The rats of all groups were sacrificed on day 61 . Sacrifice procedure was performed under light anesthesia with chloroform.

\begin{tabular}{|c|c|c|c|c|}
\hline \multicolumn{5}{|c|}{ Table I } \\
\hline \multicolumn{5}{|c|}{ Experimental study design } \\
\hline \multirow{2}{*}{ Groups } & \multirow[t]{2}{*}{$\mathrm{n}$} & \multicolumn{2}{|c|}{ Treatment schedule } & \multirow{2}{*}{$\begin{array}{c}\text { Sacrifice } \\
\text { day } 61\end{array}$} \\
\hline & & Day 1 to day 30 & Day 31 to day 60 & \\
\hline Control & 6 & Food and water ad Libitum & Food and water ad libitum & \\
\hline Arsenic & 6 & $\begin{array}{l}\text { Arsenic contaminated drinking water }(200 \mu \mathrm{g} / \\
\mathrm{L})+ \text { food ad libitum }\end{array}$ & Food and water ad libitum & \\
\hline Extract & 6 & Food and water ad libitum & Extract $(200 \mathrm{mg} /$ day $)+$ food and water ad libitum & \\
\hline Arsenic plus extract & 6 & $\begin{array}{l}\text { Arsenic contaminated drinking water }(200 \mu \mathrm{g} / \\
\mathrm{L})+ \text { food ad libitum }\end{array}$ & Extract $(50 \mathrm{mg} /$ day $)+$ food and water ad libitum & \\
\hline Arsenic plus extract & 6 & $\begin{array}{l}\text { Arsenic contaminated drinking water }(200 \mu \mathrm{g} / \\
\mathrm{L})+ \text { food ad libitum }\end{array}$ & Extract $(200 \mathrm{mg} /$ day $)+$ food and water ad libitum & \\
\hline
\end{tabular}




\section{Collection and preservation of organs}

Organs (liver, kidneys, intestine and skin) were collected after opening the abdomen of rats by midline incision. Then, these were packed in separate polyethylene packets with labeled and preserved in a deep freeze until analysis.

\section{Preparation of tissue homogenate}

At first, the tissue was taken separately in a petri dish containing distilled water (resting in an ice bath) and clean properly. Then, $500 \mathrm{mg}$ of each experiment tissue after blotting on filter paper was weighted. This was chopped into small pieces (1-2 $\mathrm{mm}$ in size). Two milliliter of distilled water and chopped tissue were taken in a hand homogenizer that placed in an ice bath. The tissue was homogenized. Carefully transferred homogenates to the labeled amber color container and kept at $-20^{\circ} \mathrm{C}$ before use

\section{Results}

The acute toxicity study using the brine shrimp

\section{Table II}

Number of live nauplii at different concentrations of the extract

\begin{tabular}{|crrr|}
\hline $\begin{array}{c}\text { Concentration of } \\
\text { extract }(\mu \mathrm{g} / \mathrm{mL})\end{array}$ & Hour 0 & Hour 2 & Hour 24 \\
\hline 0 & $10 \pm 0.0$ & $10 \pm 0.0$ & $8 \pm 1.5$ \\
1 & $10 \pm 0.0$ & $9 \pm 1.5$ & $7 \pm 1.0$ \\
50 & $10 \pm 0.0$ & $7 \pm 1.0$ & $5 \pm 0.5$ \\
200 & $10 \pm 0.0$ & $8 \pm 1.1$ & $6 \pm 0.5$ \\
1000 & $10 \pm 0.0$ & $8 \pm 1.0$ & $7 \pm 0.5$ \\
\hline
\end{tabular}

shows that $M$. charantia extract had little effect (Table II).

\section{Liver}

The mean $( \pm$ SD) amount of arsenic in the liver in the control group was $5.6 \pm 4.8 \mu \mathrm{g} / \mathrm{g}$ which was increased to $12.5 \pm 6.5 \mu \mathrm{g} / \mathrm{g}$ after ingestion of arsenic for 30 days (Table III). The administration of $50 \mathrm{mg} \mathrm{M}$. charantia extract (arsenic plus extract 50 $\mathrm{mg}$ ) reduced the mean amount of arsenic to $1.1 \pm 2.5$ $\mu \mathrm{g} / \mathrm{g}$ which was $91.2 \%$ less than the arsenic group. This change was statistically significant $(p=0.002)$. The administration of $200 \mathrm{mg} M$. charantia extract (arsenic plus extract $200 \mathrm{mg}$ ) reduced the mean amount of arsenic to $3.4 \pm 4.0 \mu \mathrm{g} / \mathrm{g}$ which was $72.8 \%$ reduction when compared to the arsenic group. This change was also statistically significant $(\mathrm{p}=0.015)$.

\section{Kidneys}

The exposure of rat to high concentration of arsenic lead to the amount of arsenic in kidneys $17.2 \pm 9.0$ $\mu \mathrm{g} / \mathrm{g}$ from the control value of $3.5 \pm 4.2 \mu \mathrm{g} / \mathrm{g}$ (Table III). The administration of $M$. charantia extract (50 $\mathrm{mg}$ ) reduced the mean amount of arsenic to $2.9 \pm 3.4$ $\mu \mathrm{g} / \mathrm{g} \quad(83.1 \%$ reduction). This change was statistically significant $(p=0.004)$. The administration of $200 \mathrm{mg} M$. charantia extract reduced the mean amount of arsenic to $3.5 \pm 4.9 \mu \mathrm{g} /$ $\mathrm{g}$ which was $79.7 \%$ reduction when compared to arsenic group. This change was also statistically significant $(\mathrm{p}=0.008)$.

\section{Intestine}

The mean $( \pm$ SD) amount of arsenic in the intestine in control group was $0.2 \pm 0.2 \mu \mathrm{g} / \mathrm{g}$. In arsenictreated group, the mean amount of arsenic in

\begin{tabular}{|c|c|c|c|c|c|c|}
\hline \multicolumn{7}{|c|}{ Table III } \\
\hline \multicolumn{7}{|c|}{ Effect of different concentrations of $M$. charantia extract on the removal of arsenic from rat liver } \\
\hline Tissue & & Control & Arsenic & Extract & $\begin{array}{r}\text { Arsenic plus extract } \\
(50 \mathrm{mg})\end{array}$ & $\begin{array}{r}\text { Arsenic plus extract } \\
\text { (200 mg) }\end{array}$ \\
\hline \multirow[t]{3}{*}{ Liver } & Arsenic concentration $(\mu \mathrm{g} / \mathrm{g})$ & $5.6 \pm 4.8$ & $12.5 \pm 6.5$ & $4.8 \pm 4.5$ & $1.1 \pm 2.5$ & $3.4 \pm 4.0$ \\
\hline & $\%$ Removal & - & - & - & 91.2 & 72.8 \\
\hline & $p$ value & - & - & - & $0.002^{\mathrm{a}}$ & $0.015^{\mathrm{b}}$ \\
\hline \multirow[t]{3}{*}{ Kidney } & Arsenic concentration $(\mu \mathrm{g} / \mathrm{g})$ & $3.5 \pm 4.2$ & $17.2 \pm 9.0$ & $3.9 \pm 4.0$ & $2.9 \pm 3.4$ & $3.5 \pm 4.9$ \\
\hline & $\%$ Removal & - & - & - & 83.1 & 79.7 \\
\hline & $p$ value & - & - & - & $0.004^{\mathrm{a}}$ & $0.008^{b}$ \\
\hline \multirow[t]{3}{*}{ Skin } & Arsenic concentration $(\mu \mathrm{g} / \mathrm{g})$ & 0 & $6.2 \pm 3.5$ & 0 & 0 & 0 \\
\hline & $\%$ Removal & - & - & - & 100 & 100 \\
\hline & $\mathrm{p}$ value & - & - & - & $0.001^{a}$ & $0.001^{\mathrm{b}}$ \\
\hline \multirow[t]{3}{*}{ Intestine } & Arsenic concentration $(\mu \mathrm{g} / \mathrm{g})$ & $0.2 \pm 0.2$ & $13.9 \pm 7.5$ & $0.7 \pm 1.3$ & $1.5 \pm 2.9$ & $1.6 \pm 1.8$ \\
\hline & $\%$ Removal & - & - & - & 89.2 & 88.5 \\
\hline & $\mathrm{p}$ value & - & - & - & $0.003^{a}$ & $0.003^{b}$ \\
\hline
\end{tabular}


intestine increased to $13.9 \pm 7.5 \mu \mathrm{g} / \mathrm{g}$ (Table III). The administration of $50 \mathrm{mg} \mathrm{M}$. charantia extract reduced the mean amount of arsenic in the intestine to $1.5 \pm 2.9 \mu \mathrm{g} / \mathrm{g}$ which was $89.2 \%$ less than the arsenic -treated group. This change was statistically significant ( $p=0.003$ ). The administration of $200 \mathrm{mg} \mathrm{M}$. charantia extract reduced the mean amount of arsenic to $1.6 \pm 1.8 \mu \mathrm{g} / \mathrm{g}$ which was $88.5 \%$ reduction when compared with arsenic group. This change was also statistically significant $(p=0.003)$.

\section{Skin}

There was no detectable amount of arsenic in the skin of control group. It increased to $6.2 \pm 3.5 \mu \mathrm{g} / \mathrm{g}$ in arsenic-treated group. The administration of 50 $\mathrm{mg} M$. charantia extract reduced the mean amount of arsenic in the skin to $0 \mu \mathrm{g} / \mathrm{g}$ (Table III).

\section{Accumulation of glutathione in rat liver}

The mean $( \pm S D)$ amount of glutathione in the liver of control group was $13.6 \pm 0.7 \mathrm{mg} / \mathrm{g}$. The administration of arsenic for 30 days in the arsenic-treated group decreased the mean amount of glutathione to $5.8 \pm 0.5 \mathrm{mg} / \mathrm{g}$. The administration of $50 \mathrm{mg} M$. charantia extract increased the mean amount of glutathione to $7.7 \pm 0.3 \mathrm{mg} / \mathrm{g}$ which was $32.8 \%$ increased than that of arsenic-treated group. This change was statistically significant $(p=0.000)$. The administration of $200 \mathrm{mg} M$. charantia extract increased the amount of glutathione to $8.6 \pm 0.2$ $\mathrm{mg} / \mathrm{g}$ which was $48.3 \%$ increased when compared to the arsenic-treated group. This change was also statistically significant $(\mathrm{p}=0.000)$ (Table IV).

\section{Discussion}

The present study has shown the significant effect of $M$. charantia ethanol extract on the removal of arsenic from the different organs of arsenic-treated rat. The percentage of the removal of arsenic by $M$. charantia was $100 \%$ in the skin, $91 \%$ in the liver, $89 \%$ in the intestine and $83 \%$ in the kidney.

\section{Table IV}

Effect of $M$. charantia extract on glutathione level in rat liver

\begin{tabular}{|c|c|c|c|}
\hline Groups & $\begin{array}{c}\text { Concentration of } \\
\text { glutathione in liver } \\
(\mathrm{mg} / \mathrm{g})\end{array}$ & $\%$ Increase & $\mathrm{p}$ value \\
\hline Control & $13.6 \pm 0.7$ & - & - \\
\hline Arsenic & $5.8 \pm 0.5$ & - & - \\
\hline Extract & $13.3 \pm 0.5$ & - & - \\
\hline Arsenic plus extract (50 mg) & $7.7 \pm 0.3$ & $\uparrow 32.8$ & $0.00001^{\mathrm{a}}$ \\
\hline Arsenic plus extract (200 mg) & $8.6 \pm 0.2$ & $\uparrow 48.3$ & $0.00001^{\mathrm{b}}$ \\
\hline
\end{tabular}

In the present study, the less amount of arsenic was found in different organs of the control group. It is due to the inevitable presence of arsenic in normal drinking water and food. The amount of arsenic was increased in the different organs of rats following administration of $200 \mu \mathrm{g} / \mathrm{L}$ of arsenic for every day. The levels were compared with that of the control group. After arsenic administration, the highest accumulation of arsenic was found in the kidney following liver, intestine, and skin. This finding was similar to another study. $\underline{10}$

The incidence of kidney pathology in chronic arsenic poisoning is uncommon. There is a causal relationship between arsenic exposure in drinking water and bladder cancer.11 The prolong exposure to arsenic may cause accumulation within the red blood cell.

As a result, arsenic accumulation is increased in the reticuloendothelial rich organs like the liver. Inorganic arsenic is metabolized and rapidly cleared from tissues through urine. 12 This biomethylation process can easily become saturated. Thus, it leads to the excess inorganic arsenic being deposited in the skin, hair, and nail, where it binds tightly to keratin. In this study, there were two arsenic exposed groups, where the different concentration of extract 50 and $200 \mathrm{mg}$ were given every day. The study showed that arsenic was removed in different concentration from different organs in the different rates. Extract $50 \mathrm{mg}$ was more effective in the removal of arsenic from the kidney and liver. In case of intestine and skin, removal of arsenic by 50 and $200 \mathrm{mg}$ showed the same effect. There was significantly decreased glutathione level in the liver after arsenic administration. Different concentration of the extract was increased the glutathione level, $32.8 \%$ in $50 \mathrm{mg}$ and $48.3 \%$ in $200 \mathrm{mg}$.

A number of studies are available on the removal of arsenic from the different organs by the different extract. Corn extract (water) reduced the highest percentage of arsenic from the liver tissue 69\% followed by kidney- 64\%, skin- 69\%.10 Spinach extract (1\%) removed the arsenic from the liver in $76 \%$, kidney- $44 \%$, intestine- $57 \%$, and skin- $63 \% . \underline{.13}$

Another study done by Quayum, 2007 showed the effectiveness of the root Eichhornia crassipes extract on the removal of arsenic from different tissues in $60 \%$ in the liver, $48 \%$ in the intestine, $43 \%$ in the kidney, and $35 \%$ in the skin. $\underline{14}$

It was observed that removal of arsenic from all the tissues by $M$. charantia was higher than the other extract. In the present study, it was found that $90 \%$ arsenic reduced by the $M$. charantia in comparison with the other extract such as $67 \%$ by the corn, $60 \%$ by the spinach, $46 \%$ by the root Eichhornia crassipes. Different studies have shown that there are certain phytochemicals of $M$. charantia detoxify many toxic agents. This detoxifying property helps in the remo- 
val of arsenic.

Arsenic decreased the glutathione level in liver. $\underline{15}$ Administration of arsenic in rats produced a significant reduction in hepatic glutathione. $\underline{16}$ The present study also showed that there was significantly decreased the glutathione in the liver. Arsenic can reduce the cellular level of glutathione by three mechanisms. At first, reduction of pentavalent to trivalent arsenicals occurred by glutathione which acts as an electron donor. Secondly, arsenic has the high affinity for glutathione. The third one is arsenic -induced free radicals decreased glutathione level by oxidation.

Certain amino acid like cysteine, vitamins like ascorbic acid and minerals have an important role in reducing the oxidative stress. Arsenic exposure causes the higher accumulation of arsenic in different organs. M. charantia is rich in vitamins, minerals, and amino acid. So, it is helpful in reducing the oxidative stress and declining the arsenic burden from the different tissues.

\section{Conclusion}

M. charantia extract reduces of arsenic level from different organs of the arsenic-loaded rat.

\section{Ethical Issue}

Prior to the study conduct, ethics for animal study were followed: a) Animals were only used as a least resort; b) Every practical step was taken to avoid distress or suffering of animal; c) The smallest possible number of animals were used as such only 6 rats taken for each group; and d) The potential benefits had weighed against the cost to the animals, the simplest or least sentient species were used.

\section{Conflict of interest}

Authors declare no conflict of interest

\section{References}

1. Chung JS, Haque R, Mazumder DNG, Moore LE, Ghosh N, Samanta S, Mitra S, Hira-Smith MM, von Ehrenstein O, Basu A, Liaw J, Smith AH. Blood concentration of methionine, selenium, betacarotene and other micronutrients in a case-control study of arsenic-induced skin lesions in West Bengal, India. Environ Res. 2006; 101: 230-37.

2. Kamaluddin M, Misbahuddin M. Zinc supplement on tissue arsenic concentration in rats. Bangladesh Med Res Counc Bull. 2006; 32: 87-91.

3. Saha B. Effect of ascorbic acid on reduced gluta- thione level in arsenic-loaded isolated liver tissues of rat. Bangladesh J Pharmacol. 2006; 1: 68-71.

4. Spallholz JE, Boylan LM, Rahman MM. Environmental hypothesis: Is poor dietary selenium intake an underlying factor for arsenicosis and cancer in Bangladesh and West Bengal, India? Sci Total Environ. 2004; 323: 21-32.

5. Ramanathan K, Shila S, Kumaran S, Panneerselvam C. Protective role of ascorbic acid and a-tocopherol on arsenic-induced microsomal dysfunction. Hum Exp Toxicol. 2003; 22: 129-36.

6. Misbahuddin $M$, Islam $A Z$, Khandker S, IfthakerAl-Mahmud, Islam N, Anjumanara. Efficacy of spirulina extract plus zinc in patients of chronic arsenic poisoning: A randomized placebo-controlled study. Clin Toxicol. 2006; 44: 1-7.

7. Myhrstad MCW, Carlsen H, Nordstrom O, Blomhoff R, Moskaug JQ. Flavonoids increase the intracellular glutathione level by transactivation of the $\gamma$ -glutamylcysteine synthetase catalytical subunit promoter. Free Radic Biol Med. 2002; 32: 386-93.

8. Wang Y, Zhao F, Jin Y, Zhong Y, Yu X, Li G, Lv X, Sun $G$. Effect of exogenous glutathione on arsenic burden and NO metabolism in brain of mice exposed to arsenite through drinking water. Arch Toxicol. 2011; 85: 177-84.

9. Sarah QS, Anny FC, Misbahuddin M. Brine shrimp lethality assay. Bangladesh J Pharmacol. 2017; 12: 186-89.

10. Chowdhury NJA, Misbahuddin M, Rahman MS. Corn extract lower tissue arsenic level in rat. Bangladesh Med Res Counc Bull. 2009; 35: 21-25.

11. Chen CJ, Chen CW, Wu MM, Kuo TL. Cancer potential in liver, lung, bladder and kidney due to ingested inorganic arsenic in drinking water. $\mathrm{Br} \mathrm{J}$ Cancer. 1992; 66: 888-92.

12. Le XC, Ma M, Cullen WR, Aposhian HV, Lu $\mathrm{X}$, Zheng B. Determination of monomethylarsonous acid, a key arsenic methylation intermediate, in human urine. Environ Health Perspect. 2000; 108: 1015-18.

13. Umar BU. Effect of hexane extract of spinach in the removal of arsenic from rat. Bangladesh J Pharmacol. 2007; 2: 27-34.

14. Quayum SK. Effect of water hyacinth root extract on arsenic level in different organs of arsenictreated rat. Bangladesh J Pharmacol. 2007; 2: 73-80.

15. Ramos O, Carrizales L, Yanez L, Mejia J, Batres L, Ortiz D, Díaz-Barriga F. Arsenic increased lipid peroxidation in rats tissues by a mechanism independent of glutathione levels. Environ Health Perspect. 1995; 103: 85-88.

16. Maiti S, Chatterjee AK. Effects on levels of glutathione and some related enzymes in tissues after an acute arsenic exposure in rats and their relationship to dietary protein deficiency. Arch Toxicol. 2001; 75: 531-37. 